\title{
THE EMERGENCE OF SKINHEADS IN THE CSSR ${ }^{1}$
}

\author{
Radek Rákos
}

\begin{abstract}
The first remarkable signs of the skinhead subculture, according to the current literature, date back to 1985, but the first signs of skinhead can be traced between 1983 and 1984 . The anti-communist mood in society and growing community intolerance towards the gypsy population have paved the way for far-right thinking. This was further stimulated by the infiltration of news from foreign medias, which considered ultra-right action to be a sensation, and because of this marketing step, the population was so supplied with hot news. The relationship between the punk movement and the skinhead subculture is basically that skinheads are merging from punk movement because of the influence of socalled Oi movement or by the imagination of foreign media, such as the $100+1$ magazine of foreign interests. The right-wing skins experienced its own Renaissance when the Orlík music group emerged, which, however, evaded from neo-Nazism promoted abroad and built its values on patriotism and racism, although some of those texts attracted a number of those fans. With the collapse of the communist regime and the opening of the information flow, several subcultures began to be profiled by yet unavailable information.
\end{abstract}

\section{Keywords}

punk rock, skinheads, racism, alternative scene, subcultures

\section{Introducing the issue of the newly uprising Nazi skinheads}

"In the United Kingdom at the turn of the 1970s and 1980s, the problems of immigration have culminated. It is estimated that in the 1950s the number of immigrants in the UK was $4 \%$ of the population, or almost two million people." (Morgan et al., 1999, p. 351). The local government first supported immigration, due to the vision of cheap labor. This fact, however, worried local people heavily because they had a fear of loss of their work. Increased hostility among immigrants and indigenous peoples was also increased by the

\footnotetext{
$\overline{1}$ The work was supported by the grant SVV number 260461 Interests, power, and institutions in political decision-making.
} 
laws favoring immigrants. The government subsequently sought to alleviate the situation by retroactively tightening immigration and wage laws. But it was too late. The reaction to these events was the terrorist invasion controlled by the neo-fascist organization socalled neo-Nazi skinheads, which have severed themselves from traditional skinheads and their ideology has begun to turn to right-wing extremism. Neo-Nazi skinheads attacked the immigrant population not only in an organized manner, but also randomly, not only creating a strong rancor, but they also changed the view of the population to the skinhead movement itself. Those skinheads were largely influenced by the National Front, which, like Hitler, created striking units to promote its goals. A few years earlier, they tried to do it through the punk movement, but they did not have a remarkable success. "Its greatest influence has been achieved by the National Front in the 1970s and 1980s." (Holmes, 1988, p. 264)

In this unpleasant atmosphere politicizing of those skins occurred, of which the most important was lan Stuart Donaldson, which established the so-called White Noise Club, which was a music publisher focused on racist-oriented skinheads. The establishment of the RAC (Rock against Communism) platform followed, the establishment of RAC can be understood as the so-called recruitment of the same-minded skinheads. Around the first half of the 1980s the skinhead movement gets into other European countries. Thanks to the great response of the mass media, which skinheads displayed as racist and right-minded, this movement has started to be assigned with the basis of Nazism and the Italian and Spanish ideas of fascism in the public. In Czechoslovakia, the spreading circumstances of the skinhead subculture were somewhat different. Aversion to communism was the link of otherwise very different views of different subcultures. If we focus on the punk and skinsheads of the pre-revolutionary era, we can safely say they did not differ much from each other. It is therefore very likely, that the idea of RAC would be supported by both punkers and skinheads.

\section{Skinheads, those are boys, sir!}

The available publications stated, that the appearance of skinheads in our country dates to 1985. The fact is, that the skinsheads could appear earlier, as the first preserved song from band A 64 "Já nemám šajn"(I don't have a clue) from the original "Banned From the Pubs" comes from the skinhead band PETER AND THE TEST TUBE BABIES. The song has circulated Europe with a tape called "World Class Punk", which came out in 1984. Considering that the band A 64 (Operating since 1983) had been able to work on the song since 1983, there is a chance that the skinhead subculture has been known to us since 1983-1984. At least this points to the fact that, that already in this timeframe we have with us some among the alternative scene awareness of skinhead music production, although they did not have to associate this creation with the skinhead subculture itself. As already mentioned above, the information came through the Iron Curtain in very difficult manner and in a rather inaccurate form. "While it was possible (Although usually illegally) to get some music from the West (foreign radio stations, music market 
exchanges, exceptionally even tolerated programs in Czechoslovak Radio and later TV), the essence of subcultural style and ideology was much worse." (Janeček \& Bittnerová, 2011 , p. 90). That is precisely why the emerging subculture among us with inspiration from international media tried as much as possible to imitate foreign subculture. However, members of subcultures in Czechoslovakia have often failed to distinguish differences between subcultures themselves, and therefore created their own form based on the presentation of the subculture by the foreign media. However, due to the total inaccessibility of appropriate resources, from which it would be possible to imitate the proper visage, here almost reaches the top of the phenomenon of DIY (Do it yourself). "Punks uses black dye on medical cloth trousers and heavy leather boots are replacement by military boots or work boots." (Janeček \& Bittnerová, 2011, p. 90)

Another controversial feature of the communist regime was insensitive approach to Gypsies, especially the Discrimination Act the 1958 Permanent Settlement Act. "Increase in gypsy population due to immigration from Slovakia and a different way of life for its members has led to an increase in ethnic tension already in the communist era between "White" and the Gypsy population in many locations, which however dampened the regime in various ways (not informing, de facto "bribing" Gypsies, etc.)." (Mareš, 2003, p. 165). This caused that, compared to the world scene, where punk from its roots has been associated with non-racist or anti-fascist tendencies, it is just in our country, based on those growing racist tensions, we could find first aggressions from the punk subculture. These racist-oriented punkers, were later mostly first Czechoslovak skinheads. "It is just the opportunity to implement and justify violence against gypsies and foreign students or workers (from Cuba, Vietnam and other third-world left-wing countries) and at the same time to express anti-regime attitudes has tempted the first individuals to create Czech skinheads." (Smolík, 2010, p. 145)

Despite this, however, until November 1989 was not a significant number of followers. It is believed that the number of poorly profiled skins ranged between 70-90. The skinheads style in Czechoslovakia was specific in a way that in the early stages of development, students and intellectuals played a leading role and strong representation (albeit living bohemian or "living in pub" style) as opposed to purely workers skinhead roots in Western Europe and the United States. (Smolík, 2010, p. 145)

One of the most important news from foreign media, which is attributed to a major impulse to the creation of the Czechoslovak skinheads, is an article in the magazine "100+1 foreign attractions" with the title "Skinheads, those are boys, sir!", describing a right-wing part of the skinheads. The article contains several insights and personal experiences with the presence of many skinhead groups in European countries, ending very often with violence. The subtitle itself is intended to shock and attract readers, which our Czechoslovak youth certainly was interested in.

"In recent years, neo-Nazi politicians in Western Europe have found enthusiastic supporters among ultra-right skinheads. They are young people who were born several years after the war and whose ideas of the "fear and misery" of the Third Reich are often very inaccurate. Still, they do not want to abandon their idol, even though it is dead for over forty years. The portraits of Adolf Hitler and the swastika flags are preserved as 
a precious relic, they greet with the Nazi hail - and most importantly: they are racially intolerant. Some skinheads, though, come from unhappy social conditions, but even unemployment cannot influence their violent behavior, as well as there is no justification for the slack attitude of official places towards rising neo-Nazism" (Kromschröder, 1986). According to available publications, this article can be considered one of the biggest causes of the rise of right-wing sympathizers skinheads in our country. It does not, however, mean that newly created neo-Nazi skinheads have business in all Nazi and Fascist activities in Communist Czechoslovakia. Quite the contrary. "Skinheads did not have anything to do with neo-Nazi excesses of non-conforming youth from the mideighties (e.g. Z. Jankulovski of Totenkopf ${ }^{3}$ knew about skinheads, but to him they were "stupid people" in the West who are fighting at football matches)." (Mareš, 2003, p. 165). "The Liberation of Czechoslovakia and the introduction of a new political system, whose foundations were agreed upon by the London and Moscow resistance even during the war, meant for a long time the end of the more significant public or even legal activities of right-wing extremism and radicalism in the Czech, which was further compounded by the Communist's grasp of power in 1948." (Mareš, 2003, p. 160). The Communists have made much of a consideration that any right-wing extreme or radical tendencies are immediately prosecuted and punished. "The first phase of the post-war ultra-right is tied to pre-war and protectorate or even Nazi organizations, some of those members (even individual) members were attempting to actively engage in illegal activities and, in the new circumstances, immediately followed up on earlier activities, or for fear of being captured, they carried out anti-state activities." (Mareš, 2003, p. 161)

This knowledge is mainly underlined by numerous reports, e.g. in Rude Právo, (Czech communist newspapers) where occasional occurrences of "Terrorist acts" committed by these offenders can be traced easily. Whereas, that during the entire communist regime, no media and StB (Communist secret police) news did not distinguish individual fascist and Nazi delicts, all cases had the same label. Therefore, it is virtually impossible to tell whether any act was done under the guise of skinheads or not. It is obvious, however, that these right-wing anti-regime actions certainly became a base for newly formed ultraright skinheads.

Returning to the above-mentioned article and looking at the text itself, we will find out how the propaganda article worked. "The skulls are shaved, wearing US Air Force jackets, jeans, scuffed jeans, heavy boots with Doc Martens steel studs. Those skinheads are carrying the British flags and yelling their slogan: If you're white - you're allright. If they're black - send'em back!"' (Kromschröder, 1986).

However, the article did not focus only on the racism and xenophobia of the participants, but also on the verbal attack of the passerby black family during the parade.

\footnotetext{
2 "The leading organizer of Totenkopf. He came to Nazism because of his childhood hobby, which was plastic modeling. His father was bringing him from his trips to capitalistic countries models of German planes (including decals with Nazi emblems), this led him to acquire an interest in history of war and later to Nazism, later even Nazi theories." (Mareš, 2003, p. 164).

3 "One of the later significant activities of young neo-Nazis in the communist era was the short existence of the Totenkopf group, de facto a group of several teenagers in Brno in 1983." (Mareš, 2003, p. 164).
} 
Neither the attention nor the increased anti-Semitic mood was not missed when they meet a group of orthodox Jews. There are hate speech yells like: "Jews in the Gas", "Look at those inferior people" and similar statements. (Kromschröder, 1986). After these worrying reports from London, one gets the impression that perhaps is in 40 years back and the famous "Hitlerjugend" 4 are back. The very cause of these unrest originates at the very end of the march, in the moment when the march ends in one room. "Then the chairman of the National Front ${ }^{5}$ Martin Wingfield speaks: I do not want to see any big roaring groups, but small inconspicuous clusters that strikes unexpectedly". (Kromschröder, 1986).

Following the dissolution of the party, the groups are divided in all different directions, with various racial attacks on minorities occurring on the part of the indoctrinated skinheads. These racist attacks have been more and more common with the fascist tendencies in other countries, creating support for radical youth. In Spain, skinheads are associations at the Nazi organization Cedade, Norway is home to Nordiska Rikspartiet (The Norwegian Empire Party), in Austria: Action of the new alt-right. (Kromschröder, 1986).

As can be seen from the above-mentioned article, right-wing skins have achieved attention not only on the scale of their own state, but also on the international level. Their radical behavior was a hot topic and a jewel on each reporter's report. As a matter of fact, in a certain way the mass media are responsible for extending this extreme rightwing ideology to the global level.

\section{Skinheads in Czechoslovakia, right-wing in the left-wing state}

The first visible results of the spread of the skinhead subculture in our countries were reflected in the formation of a band so-called Oi Oi HUBERT MACHÁNĚ. This punk band originated in 1983, when she first appeared at the festival in Ostrov nad Ohrí. The name of the band has two reasons. The first was a satirical reaction to Hubert Koch's photo from the German ensemble, which he was being depicted on it with a very funny clothing on. The second part of the band name is related to the character from the film "Jára Cimrman, ležící a spíci", where the Emperor's twin Macháně appears. But the most notable is the beginning of the band's name, because "Oi Oi Oi", is the name of a song from an English punk rock band COCKNEY REJECTS, who first played it in the 1980s. The name "Oi Oi Oi" is not accidental since it has been a slang salute for so-called working class in England for years. Very quickly the designation "Oi" became the link of not a racist branch of skins and punkers. Oi! is a simple punk enriched sometimes by the ska passages. Danics and Kamín (2008) to the above, states that this concept revives the non-political nature of the movement in the form of a special social protest current society.

\footnotetext{
4 Hitlerjugend aka. Hitler youth, was one of the first Nazi, militarized propaganda organization in which there were mainly boys in age between 14-18. Main goals of this organization were the spreading of antisemitism, racism, and white race supremacy.

${ }^{5}$ Already mentioned fascist party with a name National Front.
} 
So, it is clear that we have somehow got information about this new scene. However, the extent to which our listeners have been able to combine context is already the subject of speculation. The band's protagonists themselves express like this: "We just learned to play, then we heard the Oi somewhere, we liked it, and so we started using that in our texts," said Tomáš Hájíček in Rock \& Pop, 1991. And Mirek Macháček said: "Inspiration is in stupidity. With the songs, and that's the main thing, we do not want to tell anyone anything. They rank us as a skinhead band, which, I think, we are not. The main thing is good bigbeat and having fun." (Hrabalík, n.d.-b). This subject has been discussed with members of the band several times during various interviews. On their official site, they then comment on the skinhead subculture as follows: "None of us knew what Skinheads were and what Oi meant, and even though we knew bands like Angelic Upstarts, Sham 69, Cockney Reject and others that are now considered skinhead, for us it was another wave of punk bands linked to Sex Pistols, Clash and Damned." (Hubert Macháně Historie, n.d.). But the most controversial was the production of the band, which in some of its pieces is racist. One of them was a song called "Práskni negra do hlavy" meaning shoot the nigger it the head or "Bílej rajón." meaning white district.

Unity in the white circle is the correct order

all for one, one for all in the state ${ }^{6}$

I want a white district, so I would not have to fear, ${ }^{7}$ that they will rape a whole nation You would like it as well

Well damn, why are you just standing there and why do you fear We are your power intelligence is murderer $^{8}$

I want a white district, so I would not have to fear, that they will rape a whole nation You would like it as well, so what

Put yourself together and let's go we are on the right path' so let's go time is right (Hubert Macháně - Bílej rajón, n.d.)

After analyzing the text, one can notice the similarity with the way media was showing racist part of skinheads. Whether there is a connection between Oi Oi HUBERT MACHÁNĚ and right-wing skins, may be true, but not necessarily. The answer itself is irrelevant for understanding the tendencies of bands. The fact that the band has distanced itself from the skinhead subculture does not at all deny racist, xenophobic and nationalist thinking.

\footnotetext{
6 The first two verses clearly indicate the superiority of the white race and the nationalist tendencies.

7 Right from the next statement, we can clearly feel xenophobic behavior, which is aimed primarily at the Gypsy community. Also, we can see at the beginning of the song itself, that $i$ tis mimicking gypsy dialect.

${ }^{8}$ Another verse looks as if it should reach out to other white fellow citizens.

${ }^{9}$ End of the song have similarities to the recruitment tool, when text tells them they are the right side.
} 
"It is a fact that at the time of the first period of the "macháňovcü", the skinheads in the whole country could be counted on the fingers of one hand. But there were many socalled militant punks whose philosophy was approaching skinhead subculture." (Hrabalík, n.d.-b). "More surprising for the public is the alliance of punkers with skinheads, who are perceived to be the mortal enemies for they have completely different values and aspirations." (Kolářová \& Oravcová, 2011, p. 71). In our countries, however, they had a common enemy, and that was a socialistic state, which thanks to the often interventions managed to unite a lot of subcultures. "Many of those friendships, however, are the result of the fact that many punkers during adolescence choose skinhead identity as a compromise between youth rebellion and responsible adult life as a conformist." (Kolářová \& Oravcová, 2011, p. 71)

The band concerted, like other punk bands of this time, especially in unofficial places, so they never met a more prominent audience. The band mostly dealt with cover and funny songs. Their scope of the first period ends in autumn 1986, when they played the last concert in Liberec. Macháňovci came together three years later in the original set, but with a slightly changed name to HUBERT MACHÁNĚ. They became active during the 1990s, when they made their own LP-album. In 1991 T. Hájíček left and founded his own band KRUCIPÜSK.

Another fact that affected founding of skinheads was, as well as underground, which as a first founded, some punks tended to subculture of skinheads. We can see this effect for example with the punk group initiators. For Example: Limburský, which started with a KEČUP, they he made his way to the band A 64, and later found himself in 1989 with the famous band ORLík.

The opposite view of punk-skinhead symbiosis, which was opposing the ideology of a communist regime brings and interview with the man known as Jižan, he was a skin since 1985. In this interview that was made in April 2016, it turned out that above mentioned Jižan, became skinhead just because of many times mentioned article in a magazine $100+1$ of foreign interests and since then being skinhead defined him for the rest of his live. On the question if he became a skinhead after his punk phase he said: "No, no, for me punk was always a filth, I don't mean the music, but punkers, so this wasn't for me at all. At home, my dad always was listening to the relatively normal music-Rolling Stones, Olympic, Beatles and so on. So, rock music was always in my blood since I was a small kid, and still till this day. I just changed the bands that he was listening. I would never ever listen to those communistic shit like Vondračková, Gott, we never listened to those (laugh)." (Vávra, n.d.). In the next part of the interview Jižan was asked about the attitude of police, in the question it was suggested that skinheads and punkers were in the same group. "Back in the day anticommunist was everyone who stepped from the line. That doesn't mean they were our friends, for me we were definitely not the same group, skinhead did draw attention to himself, that mean I ended up on the police station very often" (Vávra, n.d.). Confirming the existence of certain conflicts between skinheads and punkers, can be confirmed from the lyrics of punk bands. One of those bands is for example HRDINOVÉ NOVÉ FRONTY, shortcut HNF, the name means heroes of the new front. In one of song they had an answer for the raising numbers of new skinheads 
influenced by an extreme right-wing ideology. Name of the song is "Skinheadská noc" meaning the night of the skinheads and premier of this song was somewhen around 1986-1987.

"Walkway shakes under the heavy boots, Chain night have begun.

The night is a swine. It speaks through the void,

Everyone is in the streets and noise is there.

Skinhead night, oi oi oi, Skinhead night, oi oi oi, Skinhead night, oi oi oi, skinhead night!

Skinhead night, when debts are paid, for outlanders it's not safe here.

Skinhead strikes on Turks are payment, if you want to welcome skins ghetto. ${ }^{10}$

Nazi already yells crazy hits, their war is in the beginning, decibel into the night never was silenced, tomorrow it will begin again."

(H.N.F. - Skinheadská noc, n.d.).

As a next thing Jižan gives an example how he was forced by the police to scratch away his decoration patch from his jacket with his keys. The fact that police was arresting young citizens on the basics of being different and thanks to the war against so called - defective youth, is an indisputable fact that can be substantiated by many materials. It is, however, very foolish to overstate the state security authorities was even able to distinguish patches and know which patch belong to which group and who owns them. Already under State Security Administration in 11 September 1986 was stated that the secret police verified the existence of certain knowledge. This knowledge was that a fascist group was created and promoted the skinhead movement in Česká Lípa. This group was supposed to focus on "especially the physical attack on Gypsy community" (X. direction ${ }^{11}$ SNB 1986). Besides one of the main attributes of the skinheads is their own fashion, that allowed for a recognition. But how was it in the early days of their origin?

\footnotetext{
10 An indisputable remark for the xenophobic subtext of Czechoslovak.

11 The X. Administration was tasked to influence Czechoslovak youth with educational means, including all kinds of repressions. The main objective was to gather information about the moods in society and from that information they developed preventive measures and analysis.
} 
Was it even a possible back then to see skinhead with the today typical "bomber"12 and "Martensky"13? "Well it wasn't impossible, but it was very hard. I got my bomber, in the autumn of 1988 in Budapest, until then I had similar green jacket. And about the boots I got them in December 1989, immediately after we could visit the west Berlin". (Vávra, n.d.). This testimony proves and confirms how much skins were un-profiled in the early beginnings, which also does not contribute to their identification within the general population and the members of the police itself.

And how was the music? Given the findings, it is obvious that it depended on the relationship between those skinheads and the other subcultures. They could go to the punk concerts if they offered at least some ideological similarities. Other option was to listen foreign skinhead bands, these cassettes were hard to find. As Jižan said: "Sure, there was few cassettes of 4-skin. Terrible copies, sure, but you could understand what the meaning was." (Vávra, n.d.). Band 4-Skins was a successor of the band COCKNEY REJECTS and became of the most prominent in Oi movement. They were singing about traditional skinhead values and so-called street life and they built their band as an apolitical skinhead band. And that was the moment when we could saw the distorted information coming from the abroad. If the information flow would be correct, for sure right-winged skinheads would despise this music.

First band in Czechoslovakia that is considered as a part of the movement Oi punk was Band with the name DO ŘADY! (Into the line!). This Slovakian band was one of the first to be based on the new wave of punk from year 1977 and the skinhead style Oi, result form was so-called skunx. Renowned for the anti-militaristic texts, which were often misinterpreted and because of that they got a label of being in a right-wing spectrum. "This misinterpreted militarism that was attributed to the band, was also caused because member of the band Hošek or also known as a "Sid"14 had great punk reputation. And his bare head phase have just began. This immediately became the subject of discussion and speculations in Czech "flowers in dumpsters"15" (Hrabalík, n.d.-a).

Song "Tak se pridej" (So join), is one of those song, that was supposed to show the antimilitaristic tendencies. "Band appeared for the first time in the November 1987 in National house in Prague, where they played 6 songs, and one cover from Siouxie \& The Banshees." (Hrabalík, n.d.-a). Then they had several successful concerts, most important from them was the illegal performance in Poland city Jacin. "Band casted $25^{\text {th }}$ place out of total 90 bands and thanks to this success they received an offer to record an LP in the Ameba studio in Katowice." (Hrabalík, n.d.-a). One of their remarkable songs that got to LP is the above mentioned song "Tak se pridej" (So join), which in itself becomes even more ironic when a year later the main protagonist of the band Volman

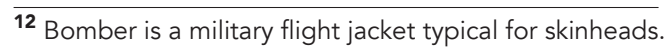

${ }^{13}$ Martensky - heavy military boots with the steel tip, typical for the working class.

14 Nickname for the singer Petr "Sid" Hoškek from band PLEXIS.

15 Name for the Czech society and fashion during 1970s.
} 
is forced to join military service. ${ }^{16}$ During the lifecycle of the band it became known as a band causing conflicts. That was because on their concerts there were punkers and skinheads. "Concert in Litochleby, where fan club of the band ŽENTOUR invited punk bands TŘI SESTRY (three sisters) a DO ŘADY! (into the line), Ended with a mass fight after a skinhead provocation. This fiasco is displayed after the revolution in the comix series in magazine Scene Report author F.E. Müller - he also depicted a fiasco from the Pilsen and band DIE TOTEN HOSEN)." (Fuchs, 2002, p. 114). "Skunnx band DO ŘADY! (Into the line) had a great influence on the Czech subcultures, mainly thanks to their contact with abroad (years 1987-1990) and had many chances in abroad to make themselves way more famous than they were". (Hrabalík, n.d.-a).

Last Band with the great influence is Band ORLíK. This pure skinhead bad was founded around year 1988. Lead singer was Daniel Landa with David Matásek playing guitar, already well-known Jan Limburský playing drums and finally Jakub Maleček with bass. Nationalistic and racist band became holy grail to the right-wing skinheads. Before the revolution they already made famous song "Bílá Liga" (white league) and one patriotic song "Čech." (Czech). In the two years of band activities, there was several racist ventures for example VLAJKA ${ }^{17}$, BRÁNÍK18, VALAŠSKÁ LIGA19. "In the opposite side there were bans for apolitical skinheads THE PROTEST, FISTBOIS, JABLONECKÝ PROTEST (later PATRIA) and more." (Kolářová \& Oravcová, 2011, p. 172). Band texts were mainly about patriotism, skinhead movement and also racism. Texts aimed mainly agins Cubans and Gypsies. They stood at the birth of a typical Czech odd called Kališníci, their main mission was patriotism, racism and fight against neo-Nazis and communists. Despite the claims of the band members, about distancing themselves from all forms of Nazism and fascism, some texts do have some elements that undoubtedly had to attract that sort of fans. We must understand that the line between patriotism and xenophobia is very thin. As well as pointing to the white race community do not have to be automatically bad, if it is used in a wider context. Typical example of this is above mentioned song "Bílá liga" (White league), which clearly determinate the point with its structure. Regardless of the group's intention, which may be whatever, the song in the first parts is supposed to provoke the audience and show the controversy regarding the presence of foreigners in our country. Refrain itself is there to have an uniting character, then its used to incite hatred to the enemy. Entire song then evokes the thoughts, about xenophobia, racism and the cohesion of the white race.

\footnotetext{
16 In Czechoslovakia military service was mandatory for all males in age for years.

17 "First phases of Naci organizations, where some members were involved in illegal activities and in new conditions they immediately followed up on earlier activities, respectively for fear of being captured, they carried out anti-state activities." (Mareš, 2003, p. 161).

18 Extremist right-wing skinhead band considered of 6 members operating since the 1990s.

19 Extremist right-wing band operating between 1987-1989. Name of the album Valmez über alles is cue about the Nazi hymn Deutschland über alles, where Valmez is a shortcut of a city Valašské Meziříčí. After the revolution this band had way more controversial texts and stopped existing in 1994.
} 
"Nothing against a tourist When they want to see

But it's impossible to live here 20

And also to work

What was that sound?

Who fell here from the palm tree?

Black eyes, black body

that is not my friend!21

White league

White league

White league is white, white

Clean your boots

Your power is in them

White power blinded me

Black spirit bleached from $\mathrm{me}^{22}$

They have different morals

manners too

they will never be like us

Do not believe in miracles ${ }^{23}$

And for a bad word

They will stab you with a knife

So why do they send

those killers here?"

(Orlík - Bílá liga, n.d.).

\section{Conclusions}

Information embargo, harsh communist regime, strong vigilance towards new trends, fear of state authorities, dull atmosphere and monotonous culture, it all played a role in punk rock formation in the eastern block dominated by one dominant party. In addition to

\footnotetext{
$\mathbf{2 0}$ Here is comment about the criminality of Cubans, they misused the immunity they had, because Cuba was our Brother state assigned by Moscow.

$\mathbf{2 1}$ In here we can see denial of socialistic brotherhood. Nonetheless without context this can be interpreted as a pure racist statement.

22 Sigh of favoriting white race with protentional militaristic underline.

$\mathbf{2 3}$ Here we can feel the denial of multiculturalism.
} 
combating and ignoring elements of human and civil rights, the communist party caused resentment and general displeasure in all possible areas of culture, social thinking, to the credibility of official media and inflexibility of the regime. Polarity between the West and the East necessarily created the exaggerated caution of the ruling officials. Trying to prevent the spread of Western ideas forced the Eastern Bloc to make security measures. So this made it harder to the citizens of the communist state.

Since the mid-1980s, the first Skinhead groups have appeared on our territory that were influenced by foreign media, which at that time portrayed this subculture as a radically right-wing individual with xenophobic and racist thinking with the basics of hitler tradition. With the massive displacement of gypsy communities has led to racist moods, so also local punkers.

The link between skinheads and punks is alarming on its own. This link can be found in many subcultures around in Czechoslovakia. More or less we could say that the members of this subculture were always living alternative lifestyle. More so thanks to the monotone culture thanks to the regime. Anyone who did not wanted to be in the mainstream regime culture was already pursued and punished. Thanks to this feelings of loneliness, emptiness helped them to unite and create the subcultures. We can find this in western countries as well, but thanks to the pursuing of the non-conformist in Czechoslovakia this was way bigger factor.

Right-wing skins blossomed after the creation of their own music, mostly band Orlík. Orlík itself avoided the neo-nacism propagated in the abroad and they build its values on patriotism and racism. Many of their fans were lured to the neo-nazism nonetheless. After the fall of iron curtain thanks to the influx of information many of these subcultures began to profile with the new informations.

\section{References}

Danics, Š., \& Kamín, T. (2008). Extremismus, rasismus a antisemitismus [Extremism, Racism and Anti-Semitism] (2 ${ }^{\text {nd }}$ extended ed.). Prague: Policejní akademie České republiky $\checkmark$ Praze [Police Academy of the Czech Republic in Prague].

Fuchs, F. (2002). Kytary a řev aneb co bylo za zdí [Guitars and Screams or What Was Behind the Wall]. Prague: Papagájův Hlasatel.

H.N.F. - Skinheadská noc [H.N.F. - Skinhead Night]. (n.d.). Retrieved May 1, 2017, from http://www.karaoketexty.cz/texty-pisni/h-n-f/skinheadska-noc-37892

Holmes, C. (1988). John Bull's Island. Immigration and British Society 1871-1971. Hong Kong.

Hrabalík, P. (n.d.-a). Kapely - Do řady! [Bands - Into the Line!]. Retrieved April 30, 2017, from http://www.ceskatelevize.cz/specialy/bigbit/kapely/2672-do-rady/ 
Hrabalík, P. (n.d.-b). Kapely - Oi Oi Hubert Macháně [Bands - Oi Oi Hubert Macháně]. Retrieved April 30, 2017, from http://www.ceskatelevize.cz/specialy/bigbit/kapely/2615oi-oi-hubert-machane

Hubert Macháně - Bílej rajón [Hubert Macháně - White District]. (n.d.). Retrieved April 30, 2017, from http://www.diskografie.cz/hubert-machane/zazdili-nam-wc/bilej-rajon/

Hubert Macháně - Historie [Hubert Macháně - History]. (n.d.). Retrieved April 30, 2017, from http://www.hubertmachane.cz/historie.html

Janeček, P., \& Bittnerová, D. (2011). Folklor atomového věku: kolektivně sdílené prvky expresivní kultury v soudobé české společnosti [Folklore of the Nuclear Age: Collectively Shared Elements of Expressive Culture in Contemporary Czech Society]. Prague: Národní museum [National Museum].

Kolářová, M., \& Oravcová, A. (2011). Revolta stylem: hudební subkultury mládeže v České republice [Revolt by Style: Musical Youth Subcultures in the Czech Republic]. Prague: Sociologické nakladatelství (SLON).

Kromschröder, G. (1986). Holohlavci, to jsou, pane, chlapci [Skinheads, Those Are Boys, Sir]. 100+1, 1986(18). Retrieved April 30, 2017, from http://ray.streetpunk.cz/holohlavci. $\mathrm{htm}$

Mareš, M. (2003). Pravicový extremismus a radikalismus v ČR [Right-Wing Extremism and Radicalism in the Czech Republic]. Brno: Barrister \& Principal.

Morgan, K. O. et al. (1999). Dějiny Británie [History of Britain]. Prague: Nakladatelství Lidové noviny.

Orlík - Bílá liga [Orlík - White League]. (n.d.). Retrieved May 1, 2017, from http://www. karaoketexty.cz/texty-pisni/orlik/bila-liga-32013

Smolík, J. (2010). Subkultury mládeže: uvedení do problematiky [Youth Subcultures: Introduction to the Issues]. Prague: Grada.

Vávra, F. (n.d.). Jižan (skinheadem od roku 1985) - rozhovor (duben 2016) [Jižan (Skinhead since 1985) - Interview (April 2016)]. Retrieved May 1, 2017, from http://www.ourscene. org/rozhovory/jizan-skinheadem-od-roku-1985-rozhovor/ 


\section{Author}

Mgr. Radek Rákos

Faculty of Social Sciences, Charles University Institute of Political Studies

U kříže 661/8, 15800 Praha 5, Czech Republic

Kedar012567@seznam.cz 